\title{
A virtuális valóság mint szimulációs módszer alkalmazása a telepített sürgősségi egységek, valamint COVID-19-kórházak személyzetének képzésében
}

\author{
Turucz Emilia dr. ${ }^{1}$ - Truta Teodora Sorana dr. ${ }^{1}$ - Jerzicska Ernő dr. ${ }^{2}$ \\ Boeriu Marius Cristian dr. ${ }^{3}$ - Szedejesi János dr. ${ }^{4}$ - Azamfirei Leonard dr. ${ }^{4}$ \\ ${ }^{1}$ Maros Megyei Sürgősségi Kórház, Sürgősségi Betegellátó és Rohammentő Egység, Marosvásárhely, Románia \\ ${ }^{2}$ Megyei Sürgősségi Klinikai Kórház, Szívsebészeti Osztály, Nagyvárad, Románia \\ ${ }^{3}$ Marosvásárhelyi „George Emil Palade” Orvosi, Gyógyszerészeti, Tudomány- és Technológiai Egyetem, \\ Sürgősségi Orvostan Tanszék, Marosvásárhely, Románia \\ ${ }^{4}$ Marosvásárhelyi „George Emil Palade” Orvosi, Gyógyszerészeti, Tudomány- és Technológiai Egyetem, \\ Anesztézia-Intenzív Terápia Tanszék, Marosvásárhely, Románia
}

Bevezetés: A COVID-19-pandémia okozta nagyfokú betegszám-növekedés ellátásának érdekében az egészségügyi rendszerek gyakran a kórházak teljes átszervezésére kényszerültek. A szakállomány gyors és hatékony felzárkóztatása kulcsfontosságú ilyen körülmények között. A telepített kórházi egységek személyzetének felkészítésére a virtuális valóságban levezethető csoportos gyakorlatozás ígéretes módszernek mutatkozik.

Célkitüzés: Célunk egy telepített kórház személyzetének felkészítésére alkalmazott virtuális szimulációs gyakorlatsorozat tapasztalatainak bemutatása, valamint a létrehozott és kipróbált virtuális gyakorlatcsomagok adaptálási lehetőségeinek elméleti bemutatása a COVID-19-kórházak személyzetének gyors felzárkóztatását szolgáló gyakorlatsorozat lehetséges kivitelezése érdekében.

Módszer: Három, prototípusként előállított virtuális gyakorlat került alkalmazásba két próbatanfolyam keretén belül. A virtuális színterek kialakítására az XVR szimulációs szoftvert használtuk. A gyakorlatok alkalmazhatóságának és hasznosságának kiértékelésére anonim kérdőíves felméréseket készítettünk. Az adatok feldolgozásában kereszttáblaelemzést és khi-négyzet-próbát alkalmaztunk.

Eredmények: A két próbaképzésen nyolc ország képviseletében összesen 76 gyakornok vett részt. A résztvevők 63,9\%-a szerint a módszer alkalmas ilyen jellegű gyakorlatok levezetésére, de további fejlesztéseket igényel. Véleményük, hogy technikai használata „elég könnyen” elsajátítható $(59,7 \%)$, és interaktív $(90,32 \%)$, valósághú $(45,0 \%)$ szimulációs közeget biztosít.

Megbeszélés: Eredményeink alapján a virtuális valóság egy alkalmazható módszer a telepített kórházak szakállományának valós bevetésekre való felkészítésére. A létrehozott virtuális gyakorlatcsomagok tartalma és szerkezete könnyen adaptálható egy COVID-19 ideiglenes egészségügyi egység sajátos munkakörülményeihez való gyors személyzeti felzárkóztatást szolgáló múhelygyakorlatok megszervezéséhez.

Következtetés: A virtuális valóság ígéretes oktatási eszköz, amely kiegészítheti a nagy költségekkel és bonyolult szervezéssel járó terepgyakorlatokat, megközelítve azok oktatási hatásfokát. A virtuális térben megélt tapasztalatok valós szakmai élményekké alakulnak, és hozzájárulnak egy biztonságos és hatékony munkaközeg gyors kialakításához. Orv Hetil. 2021; 162(40): 1591-1600.

Kulcsszavak: virtuális valóság, COVID-19, telepített kórház, szimulációs gyakorlatok

Virtual reality as a simulation tool for field hospital's and COVID-19 hospital's staff training

Introduction: COVID-19 pandemic imposed sudden increase in hospital admissions, thus medical systems needed to reorganize entire hospitals quite often. Quick and efficient training is of outmost importance. Virtual reality team training is a promising tool for newly organized hospital units' staff. 
Objective: Our goal was to present the usefulness and applicability of virtual simulation exercises for training of field hospital personnel and to evaluate the adaptability of these created and tested exercise packs for urgent staff training of COVID-19 hospitals.

Method: Three prototypes of virtual reality exercises were assessed through two test courses. XVR simulation software was used to create virtual environments. Evaluation of exercise applicability and utility was performed by anonymous questionnaires. Statistical data-processing was performed using contingency table and chi-square tests.

Results: 76 trainees from eight countries participated in the two pilot courses. $63.9 \%$ of the participants stated that the method is suitable for conducting such exercises, but needs further development. Its technical use is "easy enough" to learn (59.7\%) and provides an interactive (90.32\%) and realistic (45.0\%) working environment.

Discussion: Virtual reality is applicable to train field hospital staffs for real missions. The created virtual exercise packages are easily adaptable, both in content and structure, to workshops dedicated for quick training of specific COVID-19 temporary medical facility's personnel.

Conclusion: Virtual reality is a promising educational tool that can complement the expensive and laborious field exercises, with comparable training efficiency. These virtual reality experiences may become real professional memories and create swiftly a secure and efficient professional milieu.

Keywords: virtual reality, COVID-19, field hospital, simulation exercises

Turucz E, Truta TS, Jerzicska E, Boeriu MC, Szedejesi J, Azamfirei L. [Virtual reality as a simulation tool for field hospital's and COVID-19 hospital's staff training]. Orv Hetil. 2021; 160(40): 1591-1600.

(Beérkezett: 2021. február 22.; elfogadva: 2021. április 5.)

\section{Rövidítések}

COVID-19 = (coronavirus disease 2019) koronavírus-betegség 2019; EUFMH = (European Modular Field Hospital) Európai Moduláris Telepített Kórház (EMTK); SARS-CoV-2 $=($ severe acute respiratory syndrome coronavirus 2$)$ súlyos akut légúti tünetegyüttest okozó koronavírus-2;

Az új típusú koronavírus (SARS-CoV-2) által okozott COVID-19-pandémia eddig példa nélküli helyzet elé állította világszerte az egészségügyi szolgáltatórendszereket. A hullámokban jelentkező, átmenetileg kialakult nagy betegszám, valamint a speciális körülményeket igénylő COVID-19-betegek ellátása nagymértékben leterhelte a meglévő kórházakat. A helyi egészségügyi egységek adaptálására, ső́t sok esetben a teljes átrendezésére volt szükség ahhoz, hogy a rendszer hirtelen ilyen nagyszámú fertőzött beteget biztonságos körülmények között el tudjon látni.

A kórházak COVID-19 betegellátó egységgé való átalakítása és az újonnan létrehozott COVID-19-kórházak kialakítása során a meglévő személyzet áthelyezése vált szükségessé. Az újoncok alkalmazása is felgyorsult, így a fiatal és kevés szakmai tapasztalattal rendelkező betegellátó személyzet keveredett a tapasztalt, ugyanakkor a megszokott munkaközegéből kiemelt szakállománynyal. Az így kialakult munkaviszonyt még tovább bonyolította a SARS-CoV-2-vel fertőzött betegek ellátásához szükséges speciális munkakörülmény, a nagyfokú túlterheltség és az epidemiológiai helyzet adta sokrétú bizonytalanság. Nem meglepő, hogy mindez növeli az „orvosi múhibák" lehetőségét.
Egy 2013-ban közölt szakirodalmi szemle szerint a több évre visszamenőleg feldolgozott adatok összevont kiértékelése alapján az „orvosi múhibák”-nak tulajdonítható halálesetek száma 210000 és 400000 közé becsülhető évente, ami a kórházi beutalások 14-21\%-ának felel meg $[1,2]$. Egy walesi tartományban készült felmérés alapján a kórházi felvételre került betegek 11,3\%-ánál regisztráltak betegellátással kapcsolatos nemkívánatos eseményt, amelyek 59,6\%-a megelőzhető lett volna [3]. Hasonló adatok találhatók az Egészségügyi Világszervezet jelentéseiben [4]. A felmérések szerint a nemkívánatos események az esetek 92\%-ában nem egyéni mulasztásoknak, hanem többféle hozzájáruló tényezőnek a következményei $[5,6]$. A kutatások során az is kiderült, hogy az „orvosi múhibák” többsége (kb. 70\%-a) nem technikai jellegú, hanem emberi tényezókre vezethető vissza [7]. A legfontosabb befolyásoló faktorok közé tartozik a nem megfelelő, csapaton belüli kommunikáció és csapatvezetés, a helyzetfelismerés hiánya, a helytelen eróforrás-felhasználás és a rossz döntéshozatal $[8,9]$. Mindezekből következően a munkaköri kapcsolatrendszerek, a tartalmi elemek és a procedurális munkastílus fejlesztésére összpontosító szimulációs gyakorlatok rendszeres bevezetése lényeges hibaelhárítási intézkedés lehetne [10-12].

A COVID-19-fertózött betegek ellátására berendezett egészségügyi létesítmények egy telepített kórház múködési irányvonalainak és munkakörülményeinek felelnek meg. Mindkét esetben átmeneti, de maximális hatásfokkal múködő egészségügyi egység kialakításáról beszélünk, s mindezt olyan körülmények között kell biztosítanunk, hogy az ellátószemélyzet előzetesen ismeretlen kórházi körülmények között, idegen eszköztár- 
ral, a mindennapi rutintól eltérő munkastílusnak kell, hogy megfeleljen. Ilyen esetekben a gyors felzárkóztatás egy rövid és átfogó képzési program segítségével létfontosságú lehet. Kiemelten fontos lenne a közös gyakorlati alkalmazásokra való lehetőség, főleg a múköódési szabályzatok gyakorlati feldolgozásának érdekében, valamint az interdiszciplináris együttmúködés a hatékony csapatmunka kialakításához [13-15].

A hasonló célokra gyakran alkalmazott döntéshozatali, úgynevezett 'tabletop' gyakorlatok tulajdonképpen papíron és maketteken levezetett csoportos helyzetszimulációk, amelyek a kognitív és interperszonális készségek fejlesztésére jól alkalmazható interaktív gyakorlási közeget biztosítanak, de például nem feltétlenül tükrözik egy reális telepített kórház munkakörülményeit. A valós helyszínen levezetett, valamint az egészségügyi egység teljes szakállományát és vezetôségét bevetô, úgynevezett teljes skálájú terepgyakorlatok képezik jelen pillanatban a legnagyobb tudásátviteli hatásfokkal múködő képzési és felzárkóztatási módszert, de ezek rendszeres bevezetése nagy költségekkel és erőforrás-felhasználással jár [16].

A virtuális valóságban kivitelezhető egyéni, csoportos vagy multiprofesszionális katasztrófavédelmi szimulációs gyakorlatok komoly potenciált képeznek a jövőre nézve, mivel költséghatékonyak, könnyen alakíthatók, valósághüek, ugyanakkor biztonságos gyakorlási lehetőséget nyújtanak [13, 17]. A számítógép által generált virtuális térben bármilyen valós környezeti feltétel kialakítható, amely vizuális, audiovizuális vagy akár taktilis információk közvetítésével válik érzékelhetővé a gyakornokok számára, optimális feltételeket biztosítva egy kontextuális tanulás és konstruktív oktatási szemléletmód kivitelezéséhez [18]. A virtuális környezetben megélt tapasztalatok valós szakmai élményekhez hasonlóan raktározódnak el az agyban, és nagymértékben hozzájárulnak a tudásanyag, valamint az elsajátított készségek hosszú távú megőrzéséhez $[19,20]$.

A virtuális színterek lehetóséget nyújtanak a múveleti medicina és az első vonalbeli ellátás gyakorlásától kezdve a technikai és nem technikai készségeknek, valamint az interperszonális és interprofesszionális együttmúködésnek a fejlesztéséig bármilyen interaktív szimulációs gyakorlat levezetésére. A virtuális szimulációs gyakorlatok standardizálhatók, helyszíntől és oktatási közegtől függetlenül reprodukálhatók. A gyakornokok teljesítménye rögzíthető és az igényeknek megfelelően újrajátszható, lényegesen növelve ezzel az oktatási programok teljesítményét, a tudásanyag átadásának sikerességét [21, 22].

A katasztrófafelszámolási múveletek képzési folyamatában egyre gyakrabban alkalmazott, virtuálisvalóságalapú múhelygyakorlatok a jelen pillanatban elsősorban az egyéni kompetenciák fejlesztésére, a csapatokon belüli együttmúködést, illetve a vizsgafolyamatok során a gyakorlati képességek felmérését célzó szimulációk levezetésére szolgálnak $[17,23]$. A szakirodalomban nem találtunk utalást teljes skálájú, multiprofesszionális szimulációs gyakorlatok levezetésére virtuális közegben.

\section{Célkitüzés}

A közelmúltban egy uniós finanszírozási pályázat keretén belül komplex, átfogó alaptanfolyam került kidolgozásra, amely fóképp a nemzetközi telepített kórházak személyzetének felkészítését célozta meg. A pályázat eredeti célja egy Európai Moduláris Telepített Kórház (EMTK), eredeti nevén European Modular Field Hospital (EUMFH) koncepciójának kidolgozása volt. A projekt keretén belül kutatócsoportunk a virtuális valóságon alapuló múhelygyakorlatok kidolgozásáért volt felelős.

A virtuális valóság mint szimulációs eszköz először került alkalmazásba telepített kórházak szakállományának képzési folyamatában. A jelen dolgozat egyik célja a projekt keretén belül kidolgozott és két próbatanfolyamon tesztelt virtuális múhelygyakorlatok hasznosságának és alkalmazhatóságának bemutatása, valamint a gyakorlatok levezetése során nyert tapasztalataink megosztása. A dolgozat második célkitûzése feltérképezni a már kipróbált virtuális szimulációs gyakorlatcsomagok átalakítási lehetőségeit és esetleges alkalmazhatóságát a COVID-19kórházak szakállományának gyors felzárkóztatásában.

\section{Módszer}

Az EMTK-projekt egyik célkitúzése egy egységes és átfogó, kontextusspecifikus prototípus-tanfolyam kidolgozása volt, amely könnyen adaptálható bármilyen típusú, telepíthető, sürgősségi segélyszolgálati csoport alapképzésére. A létrehozott képzési folyamat egyik külön kísérleti eleme volt a virtuális valóságra alapozott múhelygyakorlatok alkalmazása. Az EMTK-pályázat célkitüzései között két próbatanfolyam megszervezése is szerepelt, amelyek célja a prototípusként elólllított, „face-to-face” alaptanfolyam valós oktatási közegben való tesztelése, hasznosságának felmérése és ezt követően tartalmának és szerkezetének véglegesítése.

A fent említett érdekeknek megfelelően a két próbatanfolyam résztvevőinek kiválasztása meghatározott kritériumok alapján történt, így a prototípusprogramot egy multinacionális, multidiszciplináris és szakmailag változatos felkészültségi szinttel rendelkező gyakornoki közösség alkalmazta és értékelte ki először. Nyolc ország képviseletében (Belgium, Németország, Franciaország, Olaszország, Dánia, Románia, Észtország, Szlovákia), a gyakornokok 10-10 fós, önkéntes nemzeti egészségügyi segélycsapatok formájába szerveződve érkeztek a tanfolyamokra. A csapatok összetételében kötelező módon volt egy kijelölt csapatvezető, legalább egy logisztikai szakember, ezenkívül egészségügyi személyzet (szakorvosok, ápolók, paramedikusok), esetenként 1-1 gyógyszerész. A gyakornokok szakmai és valós bevetésekből származó tapasztalatait szintén figyelembe vettük a beválasztás során, abból a meggondolásból, hogy a valós missziós tapasztalatokkal rendelkező, valamint a csak elméleti tudású vagy gyakorlattal egyáltalán nem rendel- 
kező egészségügyi ellátószemélyzet kiegyensúlyozott arányban legyen képviselve mindkét tanfolyamon.

A két, angol nyelven levezetett próbakurzus során a prototípus-tanfolyam tesztelése elsősorban a program tartalmi és szerkezeti kiértékelését célozta. Nem történt felmérés sem az egyéni vagy csoportos kompetenciák alakulásáról, sem pedig a prototípus-tanfolyam általános hatékonyságáról. A tanfolyam minden napján, az oktatási program végén a gyakornokok az e-mail-címükre anonim módon kitölthető kérdőívet kaptak, amely külön kitért az adott nap valamennyi oktatási tevékenységére. Ennek létrehozására a SurveyMonkey (www.surveymonkey.com; San Mateo, CA, Amerikai Egyesült Államok) online kérdőívszerkesztő platformot használtuk.

A kérdések elsősorban az oktatási tevékenység tartalmi jelentőségét és minőségét, valamint a tevékenység szerkezeti és levezetési formáját célozták. A gyakornokok tíz szempont szerint 4 fokozatú Likert-skálán értékelték az elméleti és a gyakorlati tevékenységeket, valamint a nyílt kérdésekre válaszolva szabad szöveges véleményt is adhattak. Az 1. táblázatban kiemeltük a virtuális múhelygyakorlatok kiértékelésére alkalmazott kérdés feltevéseit. Az állítások megválaszolására a „helyes”, „részben helyes”, „helytelen” és „nem alkalmazható” lehetőségek álltak rendelkezésre.

A tanfolyam tartalmi és szerkezeti feljavítása és véglegesítése érdekében a prototípus-tanfolyam napirendje mindvégig rugalmas maradt, és a résztvevők visszajelzéseihez igazodva dinamikusan alakult. Minden hozzászólást és javaslatot regisztráltunk, a lehetőségekhez mérten alkalmazásukat ki is próbáltuk, valamint a tanfolyam szerkezetének véglegesítési folyamatában feldolgoztuk.

A prototípus-tanfolyam napirendjébe három, virtuális valóságra alapozott múhelygyakorlat került, valamint egy rövid bemutató előadás a virtuális valóság gyakorlati alkalmazásairól a katasztrófafelszámolást érintő képzési programok során. A virtuális színhely kialakítására az

\section{1. táblázat $\mid$ A gyakorlatok értékelésének szempontjai}

Minden kérdésemre kaptam választ.

Az érintett témakör eddig ismeretlen volt számomra.

A virtuális szimuláció elősegítette a gyakorlat célkitűzéseinek megértését.

A virtuális valóság interaktív szimulációs közeget biztosított.

A tartalom releváns volt a tanfolyam célkitűzései szempontjából.

A tartalom releváns volt a személyes szakmai fejlődésem szempontjából.

A múhelygyakorlat időtartama megfelelő volt.

A virtuális valóság eszközhasználata egyszerű volt.

A virtuális gyakorlat elősegítette az EMTK-koncepció megértését.

Nehézkes volt követni a virtuális szimulációs gyakorlat információáramlását.

EMTK = Európai Moduláris Telepített Kórház
XVR szimulációs szoftvert alkalmaztuk (XVR Simulation, Delft, Hollandia; www.xvrsim.com). Ez egy képernyőalapú, háromdimenziós színhelyt generáló, interaktív szimulációs program, amely által bármilyen, katasztrófafelszámolással kapcsolatos helyszín magas valósághűséggel alakítható ki. A program által futtatott virtuális színtéren egy időben több résztvevő is munkálkodhat, miközben egymás észlelése és az egymás közti kapcsolatok a generált téren belül valós idejüek maradnak. Ugyanakkor a virtuális térben történő környezeti események, valamint a résztvevők által kiváltott beavatkozások azonnal észlelhetők, és valósághú láncreakciókat produkálnak.

A szoftver használatát és a hozzá tartozó teljes technikai felszerelést, valamint a kezelőszemélyzetet a Marosvásárhelyen működő Országos Vészhelyzetek Felszámolására Specializálódott Szimulációs Központ (Centrul Național De Simulare pentru Situații de Urgență) biztosította. A szimulációs rendszer technikai futóbázisa 20 számítógépból, routerekből és strukturált kábelezésből, valamint hordozható bútorokból állt. A rendszer teljes egységében szállítható, és bármilyen körülmények között beüzemelhető virtuális szimulációs gyakorlatok levezetésére.

Annak érdekében, hogy a teljes face-to-face tanfolyam és a virtuális szimulációs rendszer telepíthetőségét is kipróbálhassuk, valamint ennek feltételeit feltérképezhessük, a két próbatanfolyamot két különböző városban, eltérő helyszíni körülmények között szerveztük meg. Az első kurzust Marosvásárhelyen a már említett szimulációs központban, a másodikat pedig Temesváron, a helyi Múszaki Egyetem Központi Könyvtárának bérelt olvasótermeiben rendeztük meg.

A virtuális valóságra alapozott múhelygyakorlatok felépítését és irányelveit a 2. táblázat illusztrálja. Mint már említettük, a gyakorlatsorozatokat megelőzte egy virtuális valóságról szóló előadás. Ennek során megvitattuk a módszer releváns technikai és oktatási vonatkozásait, illetve bemutattuk a virtuális valóság néhány, katasztrófavédelemmel kapcsolatos gyakorlati alkalmazását. Az elméleti előadást követően a résztvevők a szimulátor technikai múködésével és használatával ismerkedhettek meg. Erre a célra a szimulációs rendszer valamennyi tápegységét beüzemeltük, és próba virtuális közeget hoztunk létre, amelyben a résztvevők közösen és az XVR technikai személyzet segítségével a szimulációs rendszer összes lehetséges funkcióját kipróbálhatták. Erre a technikai felkészítésre mindkét tanfolyam során egy-egy órát szántunk.

Az első múhelygyakorlat során a gyakornokok, kisebb csoportokra osztva, a virtuális térben EMTK típusú moduláris tábori kórházakat kellett, hogy építsenek, amelyeket utólag, egy virtuális séta során be is kellett mutatniuk. A munkacsoportok random módon álltak össze, de mindegyik csapatban volt logisztikai szakember és legalább egy, alapszakállományokat képviselő személy (orvos, ápoló, paramedikus). Minden csoport kapott 
2. táblázat |A virtuális közegben levezetett gyakorlatok szerkezete és irányelvei

\begin{tabular}{|c|c|c|c|}
\hline & 1. gyakorlat & 2. gyakorlat & 3. gyakorlat \\
\hline Célkitűzések & $\begin{array}{l}\text { EMTK-modellezés, virtuális } \\
\text { prototípusok építése } \\
\text { Egy telepített kórház strukturális } \\
\text { és funkcionális összetettségének } \\
\text { feltárása }\end{array}$ & $\begin{array}{l}\text { EMTK-specifikus eljárásrendek (SOP) } \\
\text { gyakorlati alkalmazása és tesztelése } \\
\text { Koordinációs, kommunikációs és együttmű- } \\
\text { ködési folyamatok gyakorlása }\end{array}$ & $\begin{array}{l}\text { EMTK erő-eszköz tartalékok átszervezése } \\
\text { készletfeltöltési források elakadása esetén } \\
\text { Hirtelen bekövetkező tömeges betegfelvé- } \\
\text { tel ellátásának megszervezése }\end{array}$ \\
\hline Módszertan & $\begin{array}{l}\text { 5-7 fős csoportmunka: EMTK } 3 \\
\text { dimenziós projektek készítése } \\
\text { Gyakorlati idő: } 120 \text { perc } \\
\text { Megbeszélés: } 60 \text { perc }\end{array}$ & $\begin{array}{l}\text { Komplex, teljes skálájú terepgyakorlat } \\
\text { virtuális közegben } \\
\text { Gyakorlati idő: } 90 \text { perc } \\
\text { Megbeszélés: } 60 \text { perc }\end{array}$ & $\begin{array}{l}\text { Komplex, teljes skálájú terepgyakorlat } \\
\text { virtuális közegben } \\
\text { Gyakorlati idő: } 90 \text { perc } \\
\text { Megbeszélés: } 60 \text { perc }\end{array}$ \\
\hline $\begin{array}{l}\text { Várható } \\
\text { eredmények }\end{array}$ & $\begin{array}{l}\text { EMTK-prototípusok létrehozása } \\
\text { virtuális térben } \\
\text { Csoportos megbeszélések egy } \\
\text { EMTK típusú tábori kórház } \\
\text { optimális struktúrájáról }\end{array}$ & $\begin{array}{l}\text { EMTK-eljárásrendek gyakorlása } \\
\text { Múködési irányelvek tesztelése, nehézségek, } \\
\text { speciális igények feltárása } \\
\text { Multinacionális, multiprofesszionális } \\
\text { együttmúködés gyakorlása és csapatfejlesztés }\end{array}$ & $\begin{array}{l}\text { Szakterületek közötti együttmúködés } \\
\text { Erő-eszköz tartalékok gyors átcsoportosí- } \\
\text { tása, tartalék tervek kidolgozása extrém } \\
\text { körülmények között } \\
\text { Adaptációs készségek fejlesztése }\end{array}$ \\
\hline
\end{tabular}

EMTK = Európai Moduláris Telepített Kórház

részletes listát az EMTK struktúrájába beépíthető összes lehetséges egészségügyi modulról és azok specifikus jellemzőirôl (például: sebészeti mútő, intenzív terápia, labor, radiológia, sürgősségi vagy belgyógyászati osztály, személyzeti lakótelep, ebédlő stb.). A listán szereplő egységeket a virtuális térben már a gyakorlatokat megelőzően létrehoztuk, így a gyakornokoknak csak a telepített kórház szerkezetét, a modulok sorrendjét és összeillesztését, valamint a kórházon belüli közlekedési csatornákat kellett megtervezniük. A múhelygyakorlat végén a témában jártas szakemberek irányításával, együttesen megvitattuk és kiválasztottuk a legjobbnak ítélt EMTK-prototípusszerkezetet.

A következő két múhelygyakorlat során a közösen kiválasztott, virtuális telepített kórház színterén egy-egy teljes skálájú szimulációs gyakorlatot futtattunk le. A szimulációk során a gyakornokok másfél órát dolgoztak együtt, és az EMTK legfontosabb moduljainak tevékenységeit, együttmúködését (például: sürgősségi, sebészeti és belgyógyászati osztály, mútooszoba, intenzív terápia stb.), valamint a vezetőség és a logisztikai szakemberek specifikus tevékenységeit gyakorolhatták. A résztvevők a szakterületüknek megfelelően csoportosultak, és a virtuális modulok osztályközösségét képviselve szervezték annak munkamenetét. A hangsúly az eljárásrendek alkalmazásán, az interprofesszionális együttmúködés gyakorlásán és a logisztikai problémák megoldásán volt, nem a tényleges betegellátást célozta meg. A résztvevók szabadon mozoghattak a virtuális kórház területén, és interaktív elemekre (például: virtuális páciensre, felszerelésre, berendezésre) kattintva minden lényeges információt begyújthettek a szükséges eljárások megszervezéséhez. Amint döntés született egy-egy beavatkozás vagy múveletsor szükségességét illetóen, a technikai személyzet azt azonnal láthatóvá is tette a virtuális térben, a gyakornokoknak csak a döntéshozatalra és a következmények felmérésére kellett összpontosítaniuk. Interaktív, együttmúködő, zsibongó oktatási közeg jött létre, amelyben a virtuális valóság eseményei, valamint a valós, fizikai együttmúködés észrevétlenül egybeolvadtak. A gyakornokok teljesen belefeledkeztek a virtuális kórházi életbe, miközben valósan alkalmazták és tapasztalták egy telepített kórház múködési szabályzatait. Mindkét gyakorlat elöre kidolgozott eseménysorozatot foglalt magában, amelynek megoldásait a gyakorlatokat záró megbeszélések során szakemberek vezetésével a résztvevők újratárgyalhatták.

A tanfolyamok minden napján kiküldött online felméréseken kívül, a virtuálisvalóság-alapú múhelygyakorlatok részletesebb kiértékelése érdekében egy előzetes és egy végső, gyakorlatsort záró kérdőívet is alkalmaztunk. Ezek szerkezetében egy- és többválaszos zárt kérdéstípusok, 5 fokozatú Likert-értékelőskála, valamint nyitott szöveges kérdések célozták meg a résztvevók virtuális szimulációs gyakorlatokkal kapcsolatos élményeit, véleményét a módszer alkalmazhatóságáról és hasznosságáról ebben a specifikus oktatási közegben.

Adataink feldolgozásához az SPSS 23.0 statisztikai szoftvert (IBM Corporation, Armonk, NY, Amerikai Egyesült Államok) használtuk. Az adatelemzések során kereszttábla-elemzést és khi-négyzet-próbát alkalmaztunk. A szignifikanciahatár $\mathrm{p}<0,05$-nál volt. A jelen dolgozatban csak a virtuális gyakorlatok kiértékelésére vonatkozó adatokat dolgoztuk fel. A gyakorlatsorozatok kiértékelési elemeinek összehasonlításával egyrészt a résztvevớk véleményének alakulását követtük a virtuális szimulációkhoz való „hozzáedződés” folyamatában, másrészt a két tanfolyam során levezetett azonos szimulációs gyakorlatok összehasonlításával az adott gyakorlatok fejlődését követtük.

Az EMTK-próbatanfolyamok során alkalmazott három, virtuális szimulációs gyakorlat tartalmát és szerkezetét utólag felmértük és átértékeltük egy esetleges COVID-19-kórház személyzetének gyors felzárkóztatását szolgáló múhelygyakorlatok kialakításához. Célunk a már létrehozott virtuális színterek és eseménysorozatok adaptálási lehetôségeinek felmérése volt COVID-19kórházi viszonyokhoz. 


\section{Eredmények}

A két próbaképzésen összesítve 76 önkéntes gyakornok vett részt. A kiválasztott szakállomány összetétele a következőképpen alakult: 34,7\% szakorvos, 36\% nővér/ paramedikus, 29,3\% logisztikai szakember. A résztvevók előzetes, sürgósségi segélyszolgálati missziós tapasztalatát figyelembe véve: a gyakornokok 10,7\%-a semmilyen gyakorlati tapasztalattal nem rendelkezett, $32 \%$-a vett részt hasonló jellegú terepgyakorlaton, és 37,3\%-a volt valós misszióban. Továbbá a két tanfolyam résztvevőinek 42,7\%-a rendelkezett katasztrófafelszámolásra vonatkozó oktatói tapasztalatokkal. A szakállomány összetételének arányai megfeleltek egy valódi telepített kórház személyzeti részarányainak. A gyakorlati és oktatói tapasztalatokkal rendelkező gyakornokok nagyobb aránya értékes visszajelzésekre adott lehetőséget a már meglévő viszonyítási alapok által.

Az interperszonális készségek fejlesztése szempontjából a virtuális valóság valamennyi gyakorlat során interaktív szimulációs közegnek minősült; ebből a szempontból az 1 . tanfolyam során az 1 . gyakorlat $66,33 \%$-ban kapott „helyes” visszajelzést, míg a 3 . gyakorlat már elérte a 90,32\%-os „helyes” visszajelzési arányt ( $\mathrm{p}=0,0129)$. Arra a kérdésre, hogy a virtuális közeg mennyire járul hozzá az EMTK-koncepció megértéséhez, szintén jelentős „helyes” visszajelzést kaptunk, fóleg az 1 . gyakorlatok után $(63,33 \%$ és $70,97 \%)$. Ennek aránya azonban csökkent a két komplexebb, teljes skálájú virtuális terepgyakorlatot követően (51,43\% és $43,33 \%$, illetve 48,39 és 47,62$)$, de statisztikailag nem szignifikáns módon $(\mathrm{p}=0,244$ és $\mathrm{p}=0,0926)$.

A virtuális valóság alkalmazhatóságát célzó másik fontos kérdés az volt, hogy a virtuális szimulációk valóban hozzájárultak-e a múhelygyakorlatok célkitúzéseinek szemléltetéséhez, valamint eléréséhez. Ebból a szempontból a legkevesebb „helyes” visszajelzést a 3 . gyakorlat -1 . tanfolyam kapta $(45,16 \%)$, a legtöbbet pedig az 1. gyakorlat -2 . tanfolyam $(74,19 \%)$.

A gyakornokok 66,7\%-a először vett részt virtuális közegben történő szimulációs gyakorlaton, ennek megfelelően az előzetes elvárások kérdésére a következőképpen

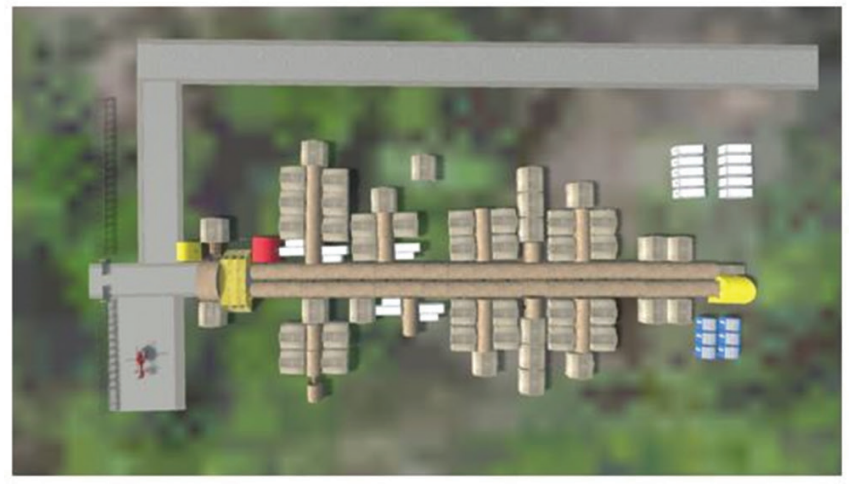

1. ábra

| Egy virtuális, telepített COVID-19 moduláris kórház szerkezete alakultak a válaszok: 30,7\% számított interaktív szimulációs gyakorlatokra, 16,0\% csapatmunkát és interprofeszszionális együttmúködést fejlesztő aktivitásokra és csak $20,0 \%$ valósághû́ szimulációs közegre. A gyakorlatsorozatok végén viszont a résztvevő́k $45,0 \%$-a igazolta vissza a virtuális közeg valósághű jellegét. A szimulációs gyakorlatok gyenge pontjaként két jellemzőt emeltek ki a résztvevő́k: hiányolták a valós végrehajtási múveleteket $(15,3 \%)$, illetve az események túl gyorsan váltakoztak $(15,3 \%)$.

Összesítve a két próbatanfolyam kiértékelését, a virtuális közegben történt szimulációs gyakorlatok megfeleltek a résztvevő́k 56,9\%-a előzetes elvárásainak. Arra a kérdésre, hogy a virtuális valóság alkalmas-e a telepített kórházak személyzetének felkészítését célzó gyakorlatok levezetésére, a résztvevő́k $63,9 \%$-a válaszolt igennel; ebből $25,0 \%$ szerint további technikai fejlesztésekre van szükség, a másik $25,0 \%$ pedig a gyakorlatok levezetésének és az információáramlás finomításának szükségességét emelte ki. Az eszközhasználat szempontjából a résztvevők 59,7\%-a úgy értékelt, hogy a virtuális valóság technikai használata „elég könnyen” elsajátítható. A tanfolyamok helyszíni, szervezési, ellátási körülményeinek általános kiértékelését illetően a két kurzus azonos pontszámokat kapott. A tanfolyamok menetét, valamint a virtuális szimulációs gyakorlatok levezetését nem befolyásolta a helyszín megváltoztatása.

Az EMTK-projekt keretében létrehozott virtuális szimulációs gyakorlatcsomagok átalakítását csapatunk három nap alatt végezte el (háromszor nyolc óra). Az első nyolc órát dokumentálásra és a témában jártas szakemberekkel való konzultálásra használtuk fel. A második nyolc óra alatt a gyakorlatok eseménysorozatát dolgoztuk át és bővítettük ki COVID-19-specifikus elemekkel. A harmadik napot pedig a virtuális színterek átalakításával és technikai próbákkal töltöttük. A meglévő eseménysorozatok általános jellegük miatt alkalmasak a COVID-19 egészségügyi egységekre jellemző belső és külső kommunikációs irányvonalak, folyamatok és szabályok gyakorlására. Átírásukra nem volt szüikség. A virtuális betegek kórlapjait viszont kibővítettük SARS-CoV2 -fertőzésre jellemző tünetekkel, így a szimulációk során

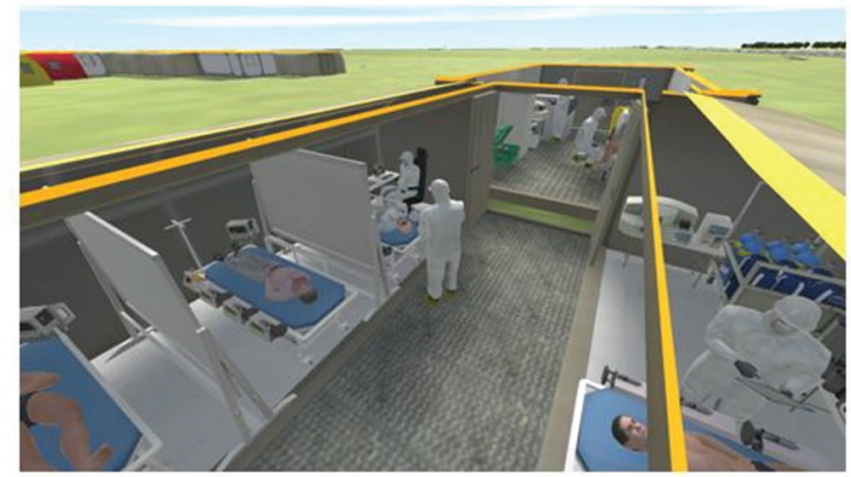


begyakorolhatók a triázseljárások, az esetdefiníciók és az elkülönítést igénylő betegek elhelyezése. A COVID-19specifikus virtuális színterek kialakításához elsősorban a specifikus elkülönítési helyek, folyosók, beöltözött személyzet hozzáadására volt szükség. Az 1. ábra egy "Három zóna, két folyosó" elve alapján felépített virtuális, COVID-19 telepített kórház szerkezetét szemlélteti, a már meglévő modulokat felhasználva.

\section{Megbeszélés}

Az EMTK-projekt során kidolgozott, virtuális valóságra alapozott, széles skálájú szimulációs gyakorlatok először kerültek alkalmazásba egy telepített egészségügyi egység személyzetének képzési folyamatában. A két próbatanfolyam során kutatócsoportunk legfóbb célkitüzése az említett képzési típus keretén belül a virtuális valóság alkalmazhatóságának és hasznosságának felmérése volt. Ennek érdekében multinacionális, multiprofesszionális, szakmai tapasztalatokban változatos gyakornoki közösséget hoztunk létre.

A múhelygyakorlatok egyik legfontosabb elemét a valós végrehajtási mozzanatok képezik, amelyek az életszerüség szimulálása miatt a gyakorlatok legköltségesebb részei. Ugyanakkor ezen beavatkozások megszervezése, koordinálása, a szükséges erőforrások és eszközök megteremtése, valamint a következmények felmérése, a kritikus gondolkodás ugyanolyan fontos, mint maguk a múveletek. A valós végrehajtási mozzanatok gyakorlása megoldható az erre specifikusan kialakított, úgynevezett skill-laborok keretén belül, viszont a múveletsorok tökéletesítéséhez és hatékony gyakorlati alkalmazásához elengedhetetlen a fent említett kognitív és interperszonális készségek fejlesztése és kontextusspecifikus gyakorlása. Ezeket a készségeket a leghatékonyabban széles körü csoportos szimulációs gyakorlatokkal lehet fejleszteni $[23,24]$. Erre a célra a széles skálájú, multiprofesszionális, koordinációs elemeket is bevonó terepgyakorlatok a legalkalmasabbak, de ezek hozzáférhetősége limitált a szervezési komplexitásuk és nagy költségvetésük miatt. Így a skill-laborokban történő képzések a legtöbbször 'tabletop' típusú gyakorlatokkal vannak kibővítve, amelyek hatékonyak ugyan az eljárásrendek begyakorlására, valamint a kognitív és interperszonális készségek fejlesztésére, de csak elméleti információkkal szemléltetik a valós munkakörülményeket. Ebből a szempontból a hatékony múhelygyakorlat alapfeltétele egy interaktív, valósághú, sokrétû szimulációs közeg, amely az éles bevetések pszichikai és fizikai stresszhatásait minél élethűben reprodukálja [25].

A virtuális közegben történő szimulációs gyakorlatok, feltételezésünk szerint, megfelelnek ezeknek az elvárásoknak. A virtuális valóságban létrehozott színterek látványhatása motiváló, fokozza a gyakornokok aktív részvételi igényét, valamint az események valós szakmai tapasztalatként való megélését $[26,27]$. A gyakornokok véleménye a virtuális telepített kórház közegében leveze- tett szimulációkról alátámasztja feltételezésünket. A résztvevők 56,9\%-a igazolta vissza a virtuális gyakorlatok hasznosságát a tárgyalt képzési folyamatban. Ugyanakkor az értékelésekből az is kitünik, hogy a virtuális szimulációs gyakorlatoknak ebben a kontextusban való alkalmazása technikai és szervezési szempontból is további fejlesztéseket igényel.

Az EMTK specifikus strukturális és múködési koncepciójának megismerésére és gyakorlására létrehozott virtuális szimulációs gyakorlatsorozatok alkalmazása kihívást jelentett mind az oktatók, mind a gyakornokok számára. A virtuális térben zajló valósághű események megnövelik a pszichés stresszhatást $[26,27]$. Ezt tovább fokozza az a tény, hogy a valóságban időigényes múveletsorok a virtuális térben sokkal gyorsabban lezajlanak, és emiatt a következmények is hamarabb felmérhetók. Mindez felgyorsítja a gyakorlatok menetét, a résztvevőknek rövidebb idő alatt sokkal több információt kell feldolgozniuk, és gyakrabban kell döntéseket hozniuk, mint a valóságban. A gyakornokok egy kisebb százaléka (15\%) ezt negatívumként jelölte meg. A többi résztvevő viszont nagy élvezettel vetette bele magát az események forgatagába, és a szabad szöveges kiértékelések során többen visszajelezték, hogy a virtuális gyakorlatok rövidebb idő alatt sokkal több és valósnak megélt szakmai tapasztalatot szolgáltatnak, mint az egyéb típusú múhelygyakorlatok.

A résztvevók 15\%-a hiányolta ugyan a valós végrehajtási mozzanatokat, a beszélgetések során több résztvevő is kifejezte, hogy pontosan a végrehajtási múveletsorok hiánya révén sikerült teljes mértékben koncentrálni a döntéshozatali folyamatokra és a múveletsorok megszervezésére. A döntések következményeinek azonnali és valósághű megjelenítése a virtuális helyszíneken szintén fokozta a felvetődő problémáknak és ezek megoldásainak valós szakmai átélését [28]. A gyakorlatokat záró megbeszélések során a résztvevők nagy átéléssel tárgyalták újra az eseményeket. Ez egy valós extrém eseményt követő, stresszlevezetést szolgáló megbeszélés hangulatát keltette.

A virtuális szimulációs gyakorlatok levezetése fokozatosan javult a két tanfolyam során. Ez a gyakornokok véleményének alakulásában is követhető. Például a 2. tanfolyam gyakorlatsorozatában a virtuális szimulációk révén már jobban sikerült mind az EMTK szerkezeti és múködési koncepciójának reflektálása, mind a gyakorlatok célkitűzéseinek teljesítése. Ezt a „helyes” visszajelzések aránya is tükrözi. Mindez az oktatók virtuális valósághoz való „hozzáedződésének” tulajdonítható. A gyakorlatokat minden esetben egy, a virtuális szimulációk levezetésében tapasztalt oktató és egy, a gyakorlat témakörének megfelelő szakértő oktató vezette. A második tanfolyam során a szakértők sokkal gyakrabban léptek közbe az események egyengetésébe, annak érdekében, hogy a gyakorlat a gyakornokok munkaritmusának és stílusának megfelelően történjen. A gyakornokok részéről szintén érzékelhető a virtuális szimulációkhoz való „hoz- 
záedződés" pozitív hatása. Például a 3. gyakorlat során az eszközhasználat egyértelmúen könnyebbnek bizonyult, valamint a virtuális szimulációk információáramlásának összetettségére vonatkozó visszajelzések aránya is pozitív irányba javult. Az oktatók észrevételei szerint a 3. gyakorlat során a résztvevők sokkal hamarabb bekapcsolódtak a már ismert virtuális kórházi életbe, jobban kihasználták a virtuális és a valós világ adta gyakorlási lehetőségeket, rutinosan szervezkedtek és múködtek együtt. Közös erővel dolgozták ki a megoldásokat.

Mindezek alapján kutatócsoportunk arra a következtetésre jutott, hogy a virtuális valóságban levezetett szimulációs gyakorlatok hatékonyságának valós felméréséhez elengedhetetlen egy több próbagyakorlatból álló „hozzáedződési” folyamat mind az oktatók, mind a gyakornokok részéról.

A jelen dolgozat második célkitüzése az EMTK-projekt keretén belül létrehozott virtuális gyakorlatsorozatok adaptálása egy COVID-19-kórház személyzetének esetleges gyors felzárkóztatását szolgáló múhelygyakorlatok előkészítéséhez.

Az 1. gyakorlathoz hasonló projektek, úgynevezett 'design' gyakorlatok, véleményünk szerint sikeresen alkalmazhatók a COVID-19-kórházak szervezési sajátosságainak hatékony szemléltetésére. A speciális elkülönítési szabályzatok gyakorlati következményei egy kórház megszokott belső szerkezetében a virtuális közegben könnyen reprodukálhatók és látványosan szemléltethetők. Erre a célra az EMTK-projekt keretében létrehozott virtuális modulok és színterek minimális kiegészítésekkel - például beöltöztető-, valamint kivetkőztetőmodulok hozzáadásával - könnyen újrahasznosíthatók. Sőt a gyakorlatcsomagot kibóvítettük egy szintén az előző gyakorlat számára kialakított virtuális sürgősségi osztály átrendezésének lehetőségével is. A gyakornokok megtapasztalhatják, hogyan nehezítik meg a mindennapi kórházi tevékenységeket ezek a szabályozások. Saját átalakítási tervek létrehozásával a háromdimenziós virtuális térben várhatóan sokkal nagyobb mértékü elfogadási és helyes alkalmazási arányt érünk el, mivel a saját projektek készítésével megtapasztalják ezeknek a járványtani szabályozásoknak a kivitelezési nehézségeit [29]. Egy jövőbeli kutatási célkitűzésünk az említett feltételezés tudományos alátámasztása.

A COVID-19-betegeket ellátó egészségügyi egységek eljárásrendjének bonyolultságát a járványügyi szabályozások adják. A szakállomány felzárkóztatásának alapfeltétele ezeknek az eljárásrendeknek a részletekbe menő feldolgozása és elfogadtatása. Ennek a leghatékonyabb módja bizonyítottan a közös gyakorlati alkalmazás [11, 12, 15]. A bemutatott próbatanfolyamok során bebizonyosodott, hogy a virtuális színterek alkalmasak a terepgyakorlatokhoz hasonló multiprofesszionális szimulációs gyakorlatok levezetésére. Egy virtuális COVID-19-kórház színterén levezetett, széles skálájú szimulációs gyakorlat véleményünk szerint hasonlóan kedvező feltételeket biztosíthat az illető egészségügyi egység speciális múködési alapelveinek elsajátításához és gyakorlásához. A 2. ábrán bemutatott virtuális közegek lehetnek például túlterhelt sürgôsségi és intenzív terápiás osztályok, valamint foglalt sürgősségi mútő együttmúködésének színterei is. Az eredeti EMTK-gyakorlatcsomagokban az

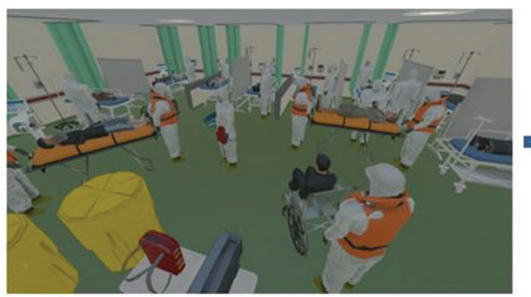

Sürgősségi ellátó

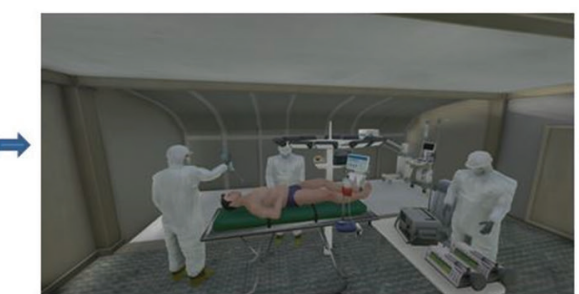

Sürgősségi mútő

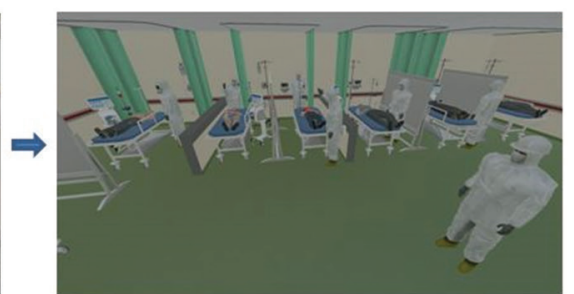

Intenzív terápia

2. ábra | Egy COVID-19-kórházon belüli interprofesszionális együttmúködést fejlesztő gyakorlat virtuális színterei
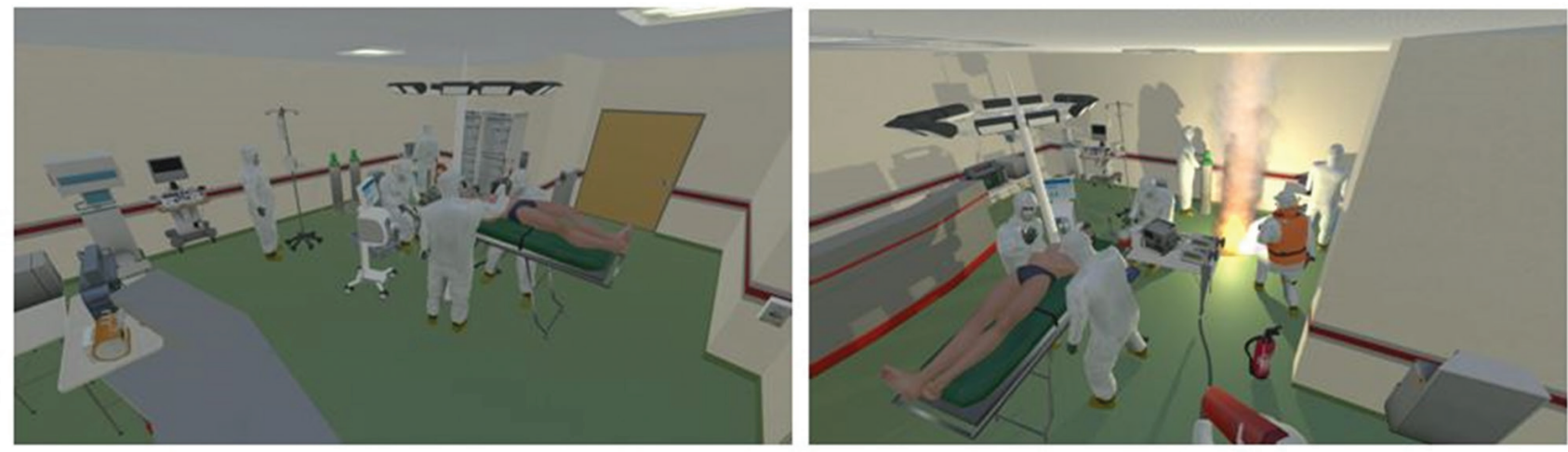
interprofesszionális kollaborálást célzó események megoldásainak kidolgozása vizuálisan megtapasztalható COVID-19-kórházi munkakörülményekre vonatkoztatva véleményünk szerint nagyon hasznos lenne a szakállomány felkészítésében. A gyakornokok fizikai beöltöztetése a szimulációs gyakorlat során pedig tovább fokozná a virtuális valóságban kialakított valósághú környezetet.

A COVID-19-osztályok túlterheltsége mind az emberi erőforrások, mind az eszközhasználat szempontjából sok, akár súlyos következményekkel járó probléma forrása lehet. A komoly stresszkörülmények között dolgozó egészségügyi szakemberek fokozott hibalehetőségeknek vannak kitéve, kiváltképp a betegellátást illetően. Az osztályok technikai túlterheltsége például múszerhasználati akadályok vagy akár tűzesetek kialakulását okozhatja. Ezek gyors felmérése és a helyzetnek megfelelő gyors elhárítási múveletek ismerete emberi életeket menthet meg. Egy nemrég közölt kutatás a sebészeti műtőben kialakuló tûzesetek során szükséges azonnali cselekvéssorozatok begyakorlására egy virtuális mútő színterén megrendezett szimulációs gyakorlatsorozatot használt fel. A kutatás eredményei arra mutattak rá, hogy a virtuális szimulációkon részt vevő gyakornokok sokkal hatékonyabban léptek közbe egy valós mútősszobában megrendezett tesztgyakorlat során, mint a hagyományos oktatási módszerekkel képzett kollégák [30]. A 3. ábra egy ehhez hasonló virtuális színtér kialakítását szemlélteti egy COVID-19-kórház részeként. A virtuális helyszín látványosan szemlélteti a védőruhába beöltözött mütőscsapat nehézségeit és járulékos veszélyeit egy ilyen baleset színterén.

A virtuális térben történő szimulációk képesek reprodukálni tantermi körülmények között a terepgyakorlatok munkakörülményeit, stressz-szintjét és hangulatát [31]. A virtuális valóság ígéretes oktatási eszköz, amely kiegészítheti a nagy költségekkel és bonyolult szervezéssel járó terepgyakorlatokat, megközelítve azok oktatási hatásfokát [31, 32]. Ugyanakkor a már létrehozott virtuális helyszínek és eseménysorozatok számtalanszor újrahasznosíthatók és könnyen átalakíthatók, újabb célkitűzések vagy célcsoportok elvárásainak megfelelően. Az EMTKprojekt keretén belül létrehozott virtuális szimulációs gyakorlatcsomagok például véleményünk szerint könynyen adaptálhatók egy COVID-19-kórház személyzetének gyors felzárkóztatását szolgáló, teljes skálájú szimulációs gyakorlatok kialakítására.

\section{Korlátok}

Tanulmányunk egyik hiányossága a virtuális szimulációs gyakorlatok hatékonyságának felmérése, de ez nem volt az EMTK-projekt célkitűzései között. Ugyanakkor erre a célra specifikus követési kritériumok kidolgozása és érvényesítése szükséges, ami egy következő kutatási projekt témája.

\section{Következtetések}

A virtuális valóságban létrehozott, telepített kórházi színtér kialakítása, valamint ennek felhasználása teljes skálájú szimulációs gyakorlatok levezetésére kutatócsoportunk által került először alkalmazásba. A két próbatanfolyam résztvevőinek visszajelzései alapján a virtuális valóság alkalmas komplex, multiprofesszionális szimulációs gyakorlatok megszervezésére, valamint egy telepített kórház virtuális gyakorlóterének kialakítására.

Véleményünk szerint a virtuális szimulációs tapasztalatokkal még nem rendelkezô célcsoportok esetén fontos lenne egy több próbagyakorlatot magában foglaló adaptálódási folyamat bevezetése, mind a technikai eszközhasználat, mind a szimulációs események kombinált, virtuális és valóságos információáramlása megszokásának érdekében.

A COVID-19-kórházak munkakörülményei sok szempontból megegyeznek egy telepített egészségügyi egység múködési viszonyaival, fóleg a személyzet átmeneti együttmúködése és az idegen alkalmazási körülmények szempontjából. A gyors felzárkóztatást szolgáló közös gyakorlati alkalmazások lényegesen csökkenthetik a hibalehetőségek arányát, valamint nagymértékben hozzájárulhatnak egy biztonságos és hatékony betegellátási egység létrehozásához.

Anyagi támogatás: A kézirat megírása anyagi támogatásban nem részesült.

Szerzői munkamegosztás: T. E.: A kéziratban szereplő gyakorlatok megtervezése, levezetése és a kérdőívek kidolgozása, kéziratszerkesztés. T. T. S: A kéziratban szereplő gyakorlatok levezetése, a kérdőívek kidolgozása, az eredmények feldolgozása. J. E.: A kéziratban szereplő gyakorlatok és a kérdőívek kidolgozása, az eredmények feldolgozása, kéziratszerkesztés. B. M. C.: A kéziratban szereplő gyakorlatok levezetése, az eredmények feldolgozása, szakmai támogatás. Sz. J.: A gyakorlatok során felhasznált kérdőívek kidolgozása, az eredmények feldolgozása, szakmai támogatás. A. L.: A gyakorlatok során felhasznált kérdőívek kidolgozása, az eredmények feldolgozása, szakmai támogatás. A cikk végleges változatát mindegyik szerző elolvasta és jóváhagyta.

Érdekeltségek: A szerzőknek nincsenek személyes érdekeltségeik.

\section{Irodalom}

[1] James JT. A new, evidence-based estimate of patient harms associated with hospital care. J Patient Saf. 2013; 9: 122-128.

[2] Makary MA, Daniel M. Medical error - the third leading cause of death in the US. BMJ 2016; 353: i2139.

[3] Mayor S, Baines E, Vincent C, et al. Measuring harm and informing quality improvement in the Welsh NHS: the longitudinal Welsh national adverse events study. NIHR Journals Library, Southampton (UK), 2017. 
[4] World Health Organization, Regional Office for Europe. Data and statistics. WHO, Copenhagen. Available from: https:// www.euro.who.int/en/health-topics/Health-systems/patientsafety/data-and-statistics [accessed: March 10, 2021].

[5] Wears RL, Leape LL. Human error in emergency medicine. Ann Emerg Med. 1999; 34: 370-372.

[6] Bleetman A, Sanusi S, Dale T, et al. Human factors and error prevention in emergency medicine. Emerg Med J. 2012; 29: 389-393.

[7] Kohn LT, Corrigan JM, Donaldson MS. (eds.) To err is human: building a safer health system. Institute of Medicine (US) Committee on Quality of Health Care in America. National Academy Press, Washington, DC, 2000.

[8] Cosby KS, Roberts R, Palivos L, et al. Characteristics of patient care management problems identified in emergency department morbidity and mortality investigations during 15 years. Ann Emerg Med. 2008; 51: 251-261.el.

[9] Zavala AM, Day GE, Plummer D. Decision-making under pressure: medical errors in uncertain and dynamic environments. Aust Health Rev. 2018; 42: 395-402.

[10] Petrosoniak A, Hicks CM. Beyond crisis resource management: new frontiers in human factors training for acute care medicine. Curr Opin Anesthesiol. 2013; 26: 699-706.

[11] Boet S, Bould MD, Fung L, et al. Transfer of learning and patient outcome in simulated crisis resource management: a systematic review. Can J Anesth. 2014; 61: 571-582.

[12] Truta TS, Boeriu MC, Copotoiu SM, et al. Improving nontechnical skills of an interprofessional emergency medical team through a one day crisis resource management training. Medicine (Baltimore) 2018; 97: el1828.

[13] McGaghie WC, Issenberg SB, Cohen ER. Does simulationbased medical education with deliberate practice yield better results than traditional clinical education? A meta-analytic comparative review of the evidence. Acad Med. 2011; 86: 706-711.

[14] Hay-David AG, Herron JB, Gilling P, Reducing medical error during a pandemic. Br J Oral Maxillofac Surg. 2020; 58: 581584 .

[15] Fitzsimons J. Quality and safety in the time of coronavirus: design better, learn faster. Int J Qual Health Care 2021; 33: mzaa051.

[16] McAlister VC. Drills and exercises: the way to disaster preparedness. Can J Surg. 2011; 54: 7-8.

[17] Bogár PZ, Tóth L, Rendeki S, et al. The present and the future of medical simulation education in Hungary. [Az egészségügyi szimulációs oktatás jelene és jövője Magyarországon.] Orv Hetil. 2020; 161: 1078-1087. [Hungarian]

[18] Gutiérrez F, Pierce J, Vergara VM, et al. The effect of degree of immersion upon learning performance in virtual reality simulations for medical education. Stud Health Technol Inform. 2007; 125: 155-160.

[19] Chittaro L, Buttussi F. Assessing knowledge retention of an immersive serious game vs. a traditional education method in aviation safety. IEEE Trans Vis Comput Graph. 2015; 21: 529-538.
[20] David D, Matu SA, David O. Psychology and technology. Fundamentals of robotics and psychotherapy through virtual reality. [Psihologie şi tehnologie. Fundamente de roboterapie și psihoterapie prin realitate virtuală.] POLIROM Könyvkiadó, Bukarest, 2015. [Romanian]

[21] Cone DC, Serra J, Kurland L. Comparison of the SALT and Smart triage systems using a virtual reality simulator with paramedic students. Eur J Emerg Med. 2011; 18: 314-321.

[22] Knight JF, Carley S, Tregunna B, et al. Serious gaming technology in major incident triage training: a pragmatic controlled trial. Resuscitation 2010; 81: 1175-1179.

[23] Gout L, Hart A, Houze-Cerfon CH, et al. Creating a novel disaster medicine virtual reality training environment. Prehosp Disaster Med. 2020; 35: 225-228.

[24] Cohen DC, Sevdalis N, Patel V, et al. Major incident preparation for acute hospitals: current state-of-the-art, training needs analysis, and the role of novel virtual worlds simulation technologies. J Emerg Med. 2012; 43: 1029-1037.

[25] Pucher PH, Batrick N, Taylor D, et al. Virtual-world hospital simulation for real-world disaster response: Design and validation of a virtual reality simulator for mass casualty incident management. J Trauma Acute Care Surg. 2014; 77: 315-321.

[26] Ferrandini Price M, Escribano Tortosa D, Nieto FernandezPacheco A, et al. Comparative study of a simulated incident with multiple victims and immersive virtual reality. Nurse Educ Today 2018; 71: 48-53.

[27] Mantovani F, Castelnuovo G, Gaggioli A, et al. Virtual reality training for health-care professionals. Cyberpsychol Behav. 2003; 6: 389-395.

[28] Mills B, Dykstra P, Hansen S, et al. Virtual reality triage training can provide comparable simulation efficacy for paramedicine students compared to live simulation-based scenarios. Prehosp Emerg Care 2020; 24: 525-536.

[29] Chen SY, Lai YH, Lin YS. Research on head-mounted virtual reality and computational thinking experiments to improve the learning effect of AIoT maker course: case of earthquake relief scenes. Front Psychol. 2020; 11: 1164.

[30] Rossler KL, Sankaranarayanan G, Duvall A. Acquisition of fire safety knowledge and skills with virtual reality simulation. Nurse Educ. 2019; 44: 88-92.

[31] Farra S, Miller E, Timm N, et al. Improved training for disasters using 3-D virtual reality simulation. West J Nurs Res. 2013; 35: 655-671.

[32] Luigi Ingrassia P, Ragazzoni L, Carenzo L, et al. Virtual reality and live simulation: a comparison between two simulation tools for assessing mass casualty triage skills. Eur J Emerg Med. 2015; 22: 121-127.

(Turucz Emilia dr., Gh. Marinescu nr. 50, Marosvásárbely, 540136, Románia e-mail: eturucz@gmail.com)

A cikk a Creative Commons Attribution 4.0 International License (https://creativecommons.org/licenses/by-nc/4.0/) feltételei szerint publikált Open Access közlemény, melynek szellemében a cikk bármilyen médiumban szabadon felhasználható, megosztható és újraközölhető, feltéve, hogy az eredeti szerző és a közlés helye, illetve a CC License linkje és az esetlegesen végrehajtott módositások feltüntetésre kerülnek. 